\title{
Marszałkowie koronni w świetle konstytucji sejmowych z lat 1504-1699. Z badań nad urzędami centralnymi Rzeczypospolitej szlacheckiej
}

W połowie XIV stulecia powstał w Królestwie Polskim urząd ceremonii i zarządcy dworu monarszego, następnie rozszerzającego swą władzę o sądownictwo karne w miejscu pobytu króla oraz zapewnienie bezpieczeństwa $w$ miejscu obrad sejmu ${ }^{2}$. Stał się on wkrótce jednym z najważniejszych urzędów w strukturze ustrojowej państwa doby monarchii stanowej. W początku następnego stulecia doszło do jego przekształcenia poprzez wyodrębnienie urzędów marszałka koronnego (marsalcus regni Poloniae) oraz jego zastępcy - marszałka nadwornego. Obaj urzędnicy funkcjonowali do końca I Rzeczypospolitej, choć w drugiej połowie wieku XVIII włączeni zostali w struktury kolegialnych organów administracji centralnej, tworzonych w ramach reformy ustrojowej państwa. Nadto od zawarcia unii lubelskiej w $1569 \mathrm{r}$. ich liczba została podwojona poprzez wprowadzenie równorzędnych urzędów w Wielkim Księstwie Litewskim.

Z uwagi na brak obszerniejszych opracowań dotyczących urzędu marszałkowskiego od XVI do XVIII wieku³ (okres wcześniejszy docze-

\footnotetext{
${ }^{1}$ Niniejsze opracowanie stanowi rozszerzenie i kontynuację badań, których dotychczasowym rezultatem były moje dwa artykuły: Z badań nad urzędem marszałkowskim koronnym w Rzeczypospolitej szlacheckiej, [w:] Studia z Historii Ustroju i Prawa. Księga dedykowana Profesorowi Jerzemu Walachowiczowi, red. H. Olszewski. Prace Wydziału Prawa i Administracji Uniwersytetu im. Adama Mickiewicza w Poznaniu, t. VII, Poznań 2002, s. 215-222 oraz Urząd marszałkowski w literaturze prawniczej XVI-XVIII wieku, [w:] Myśl i polityka. Ksiega Pamiątkowa dedykowana Profesorowi Jackowi Marii Majchrowskiemu, red. naukowa B. Szlachta, Kraków 2011, s. 377-382.

${ }^{2}$ Urząd ten mógł trafić do Polski z dworu węgierskiego, na którym Kazimierz Wielki przebywał dłuższy czas. Por. S. Kutrzeba, Urzędy koronne $i$ dworskie w Polsce, ich poczatki i rozwój do r. 1504, „Przewodnik Naukowy i Literacki” 1903, t. XXXI, s. 973 i n.

${ }^{3}$ Kilka lat temu obroniona została w Instytucie Historii Uniwersytetu Warszawskiego praca doktorska Krzysztofa Wiśniewskiego poświęcona urzędowi marszałkowskiemu w czasie bezkrólewi XVII i XVIII wieku (K. Wiśniewski, Urząd marszałkowski koronny w bezkrólewiach
} 
kał się całościowego, choć niezbyt obszernego opracowania autorstwa Stanisława Kutrzeby ${ }^{4}$ ), a także niezmiernie skąpego zasobu archiwalnego, zniszczonego w większości w wyniku działań II wojny światowej ${ }^{5}$,

XVII i XVIII wieku (1632-1736), Warszawa 2005. Praca doktorska w bibl. IH UW [P. Dr. 632/1,2,3]), niestety jak dotąd nie ukazała się ona drukiem. $Z$ autorów dawniejszych podejmowali ten temat jedynie J. Baranowski w pracy o jednym z bardziej zasłużonych i znanych marszałków - Franciszku Bielińskim (J. Baranowski, Marszałek F. Bieliński, Warszawa 1919) i J. Rafacz w rozprawie o więzieniu marszałkowskim - pisanej na podstawie istniejących jeszcze rękopiśmiennych zasobów archiwalnych (F. Rafacz, Więzienie marszałkowskie w latach 1767-1795, [w:] Studia nad historia prawa polskiego, red. O. Balzer, t. XII, z. 2, Lwów 1932, ss. 79). Na uwagę zasługują także studia F. Fuchsa nad ustrojem dworu monarszego za Stefana Batorego, gdzie sporo miejsca poświęcił autor urzędom (F. Fuchs, Ustrój dworu królewskiego za Stefana Batorego, [w:] Studia historyczne ku czci Prof. Wincentego Zakrzewskiego, Kraków 1908, s. 33-172). Jeszcze w XIX stuleciu ukazało się też kilka opracowań drobniejszych (zwłaszcza W. Suchockiego, O marszałkach wielkich i nadwornych Królestwa Polskiego, „Dziennik Warszawski” 1826, t. V, s. 193-218; J. Lelewela, Dostojności i urzędy, [w:] Polska, dzieje i rzeczy jej, t. IV, Poznań 1856, s. 21, 46-49, 80-81; J. W. Bandtkiego, Rozprawy o prawie i sadownictwie karzacem i urzędach $w$ dawnej Polsce, Warszawa 1868, s. 4446). Po wojnie zajmowali się tym zagadnieniem H. Perzanowska (Urzqd marszałkowski w okresie rzq̨ów Józefa Mniszcha, [w:] AUWr, Historia XII, 1966, nr 54 [Wrocław], s. 81-95) - opisująca urząd marszałkowski koronny w latach 1713-1742, za rządów Józefa Wandalina Mniszcha, opierając się na zachowanych w zbiorach Ossolineum fragmentach korespondencji i akt urzędowych $\mathrm{z}$ tego okresu, a także M. Wrede (Marszatkowie wielcy i nadworni koronni. Wnioski z biogramów, [w:] Władza i społeczeństwo w XVI i XVII wieku, Warszawa 1989, s. 181-193) i W. Tyszkowski (Z cenzorskiej działalności jurysdykcji marszałkowskiej w Warszawie. Spalenie numeru „, Gazette d'Utrecht z 21 czerwca 1768 r., „Ze skarbca kultury” 1980, z. 33, s. 95-104). Pierwszy podją interesującą próbę poddania analizie statusu społeczno-majątkowego marszałków, ich związków terytorialnych, stopnia kumulacji urzędu przez poszczególne rodziny, jak również dróg dochodzenia do urzędów i opcji politycznych kandydatów oraz nominatów. Drugi zajął się stosunkowo wąskim zagadnieniem wpływu jurysdykcji marszałkowskiej na cenzurę prasy w XVIII w. Przy okazji monografii i innych obszernych opracowań traktujących m.in. o strukturze urzędów w czasach staropolskich, urzędowi marszałka poświęcili miejsce np. T. Zielińska (Kwestia bezpłatności urzędów pulicznych w Rzeczypospolitej, [w:] Władza i spoteczeństwo..., s. 202-221, a zwłaszcza tejże, Magnateria polska epoki saskiej. Funkcje urzędów i królewszczyzn w procesie przeobrażeń warstwy spotecznej, Warszawa 1977), Z. Góralski (Urzędy i godności w dawnej Polsce, Warszawa 1983), S. Ciara (Senatorowie i dygnitarze koronni w II połowie XVII wieku, Wrocław 1990), M. Markiewicz (Rady senatorskie Augusta II [1697-1733], Wrocław 1988), A. Sucheni-Grabowska (Badania nad elita władzy w latach 1551-1562, [w:] Społeczeństwo staropolskie, t. I, Warszawa 1976, s. 57-119) oraz K. Chłapowski (Elita senatorsko-dygnitarska Korony za czasów Zygmunta III $i$ Wtadystawa IV, Warszawa 1996).

${ }^{4}$ S. Kutrzeba, Urzędy koronne i dworskie w Polsce, ich poczatki..., s. 973 i n.

${ }^{5}$ Zniszczeniu uległy w szczególności Akta Urzędu Marszałka Wielkiego Koronnego znajdujące się w Archiwum Głównym Akt Dawnych. Składały się na nie dwa zespoły: tzw. Archiwum Marszałkowskie Sądowe, sięgające swymi początkami XVII wieku, oraz nowsze Archiwum Marszałkowskie Ekonomiczne. Zachowane jednostki archiwalne to zaledwie 5\% dawnego zasobu. Por. J. Jankowska, Akta urzędu marszałka wielkiego koronnego 1611-1794, [w:] Straty archiwów i bibliotek warszawskich w zakresie rękopiśmiennych źródeł historycznych, t. I: Archiwum Główne Akt Dawnych, Warszawa 1957, s. 132; tejże, Akta urzędu marszałka, [w:] Straty archiwów i bibliotek warszawskich..., s. 133-139 oraz tejże, Akta urzę- 
szczególnego znaczenia nabierają konstytucje sejmowe oraz staropolska literatura prawnicza. Ponieważ o tej drugiej pisałem kilka lat wcześniej, obecnie warto przybliżyć zawarte w Volumina Legum regulacje prawne.

Pierwszy tekst odnoszący się do urzędu marszałka pochodzi ze Statutu Nieszawskiego i nosi tytuł Cancellarij, Vice-Cancellarij, Mareschalci de quibus sint Terris. Dotyczy on jeszcze marszałka dworu, który to urząd - podobnie jak urzędy kanclerza i podkanclerzego oraz inne nadworne władca zobowiązywał się obsadzać „mężami godnymi”, niezależnie od tego $\mathrm{z}$ jakiej ziemi pochodzą ${ }^{6}$.

Znacznie obszerniejszy jest fragment dotyczący tego urzędu pochodzący z uchwalonego na sejmie piotrkowskim Statutu Aleksandra Jagiellończyka z 1504 r. Po. raz pierwszy ustalono w nim dokładne zakresy działania marszałków, a także kanclerzy i podskarbich 7 . Do marszałka odnosi się tytuł: De officijis Regni et Curiae et praesertim Mareschalcorum. $\mathrm{W}$ tłumaczeniu brzmi on następująco:

„Urzędy koronne i nadworne, a szczególnie marszałków, sprawowane były dotąd $\mathrm{w}$ niewłaściwy sposób, chociaż bowiem każdy z nich zna swoje indywidualne ciężary i obowiązki, to jednak czy to z powodu rywalizacji w jednej sprawie dwu urzędów, czy też dlatego, że nie zostało ustalone, kto z nich jakie ma podejmować (czynności), dochodziło do błędów i zaniedbań w sprawach, które przypadają tym urzędom do rozpatrzenia i załatwienia, a także do wzajemnych nieporozumień między nimi. $Z$ tego więc względu należy w sposób rozumny uznać, że wykonywanie funkcji przewodniczenia wszelkim ceremoniom publicznym i zwierzchnika wszystkich dworzan winno należeć do urzędów marszałka koronnego i marszałka nadwornego, niezależnie od tego, czy na dworze znajdują się obaj, czy tylko jeden z nich. Których to (łącznie) i każdego z nich obowiązek będzie polegał na przyjmowaniu dworzan na służbę, płaceniu im, prowadzeniu regestrów, ocenianiu, którzy są pilni, a którzy opieszali, którzy dobrzy, a którzy źli i (na tym) by nie pozwalali, żeby nieposłuszni byli trzymani na dworze, lecz zawczasu oznajmiali, by tacy (ludzie) byli oddalani ze służby, na przyjmowaniu zawsze (w sposób ich wyróżniający) gości i członków rady królewskiej i czuwaniu, by ze strony majestatu królewskiego (maiestas regia) każdemu została od-

du marszałkowskiego koronnego, [w:] Archiwum Główne Akt Dawnych w Warszawie. Przewodnik po zespołach, t. I, Archiwa dawnej Rzeczypospolitej, red. J. Karwasińska, Warszawa 1958, s. 297-300.

${ }^{6}$ Item pollicemur, quo Cancellariatum, Vice-Cancellariatum, Mareschalcatum et alia officia Curiae distribuemus indistincte Iris idoneis sive fuerint de Terris Majoris Poloniae sive Cracov, $V L$, t. I, Petersburg 1859, s. 114.

${ }^{7}$ Tamże, s. 135. 
dana należna cześć stosownie do godności (sprawowanego urzędu), tak by spory (scandala) i krzywdy (excessus) albo wykluczyć, albo naprawić, wymierzając karę stosownie do przyczyny lub zawinienia. Niech więc wszystko ustanawiaja, mają staranie o wszystko i wszystkim kieruja tak w pomieszczeniach urzędowych, na dworze, w budynkach zamkowych, w komnatach i pomieszczeniach stołowych, jak i wobec innych urzędów i urzędników należących do stanu rycerskiego przy majestacie królewskim (Majestatis Regiae). W tym celu zostaje mu (urzędowi) przyznana pełna swoboda co do ustanawiania, unieważniania (zdejmowania z urzędu) i robienia wszystkiego na najlepszych warunkach oraz za zgodą i na mocy władzy majestatu królewskiego. I mimo że w odniesieniu do marszałka koronnego utrwaliło się w zwyczaju, że posiada taką władzę, iż w jego obecności marszałek nadworny nie podejmuje żadnych urzędowych czynności przysługującego mu urzędu, to jednak z uwagi na to, iż marszałek koronny częściej jest w praktyce nieobecny na dworze, po to by marszałek nadworny wiedział, że jest zobowiązany kontynuować lub wypełnić to, co słusznie w «dobrym porządku» zostało podjęte na dworze przez marszałka koronnego postanawiamy, aby te urzędy wobec siebie, bez różnicy dla obowiązków urzędowych, tak mianowicie (działały). Ilekroć na dworze jest marszałek koronny, zawsze ma przyzywać do każdego urzędowego działania i każdej czynności marszałka nadwornego i w jego przytomności ma wykonywać wszystko, co należy do urzędu marszałka. Oddalając się zaś ze dworu przekazuje regestry i wykonywanie obowiązków urzędowych marszałkowi nadwornemu. W całym wymienionym wyżej zakresie marszałek ma mieć najwyższą władzę urzędową (summa auctoritas), w razie zaś jego nieobecności, osoba sprawująca niższy rangą urząd (persona minor) ma posiadać taką samą i nie mniejszą władzę (auctoritas), jaką miał wedle zwyczaju marszałek koronny osobiście przebywający na dworze. Temu też marszałkowi kierującemu urzędem królewskiego dworu i w nim osobiście przebywającemu powierza się ze względu na zarząd pobieranie opłat targowych i uprawnienie do ustalania cen towarów sprowadzanych na potrzeby dworu. To zaś targowe ma pobierać bardziej umiarkowanie niż miał to zwyczaj czynić i w taki sposób, jaki zgodnie z prawem i zwyczajem powszechnym, w tych miastach i miejscowościach, do których przybył, w praktyce wcześniej stosowano. W odniesieniu do targu poza obszarem miasta (foro campestri) zastrzega się to uprawnienie dla hetmana wielkiego, tak żeby ceny były wyznaczane za wspólną zgodą i radą. I zarówno wtedy, gdy król przebywa w swych miejscach rezydowania, jak i poza nimi, cokolwiek rozporządzi marszałek albo hetman odnośnie do cen targowych, albo co służy do zapewnienia porządku publicznego, będzie musiał poinformować o roz- 
porządzeniu przez publiczne obwieszczenie. Jeśli zaś marszałek przekroczy miarę w odniesieniu do cen towarów i opłat targowych, członkowie rady królewskiej obecni na dworze będą mieli prawo do ograniczenia mocy tych postanowień, a także wydania własnych. Jeśli marszałek się nie będzie im chciał podporządkować, wówczas jako nieposłuszny (oporny) zostanie przekazany pod moc prawa (auctoritas communis) najbliższego zjazdu rady królewskiej (Consilium generale)".

W literaturze staropolskiej jako pierwszy wątek marszałków koronnego i nadwornego podjął Marcin Kromer, opisując w swym wydanym po łacinie w 1577 roku w Kolonii dziele, Polska, czyli o położeniu, ludności, obyczajach, urzędach i sprawach publicznych Królestwa Polskiego księgi dwie, następujące uprawnienia tego urzędu:

„Marszałek koronny jest przełożonym dworu królewskiego i nadzorcą rady państwowej; jemu przysługuje prawo zwoływania senatu na polecenie króla lub prymasa. On dba o ciszę w czasie obrad i przemówień, dopuszcza do głosu, wprowadza zagranicznych posłów, usuwa $\mathrm{z}$ rady tych, którzy do niej nie należą, ogłasza wyroki królewskie w sprawach czci i gardła, obwieszcza ludności uchwały senatu, urządza uroczystości państwowe, podejmuje znakomitych gości, uśmierza niepokoje wszczynane przez mącicieli i warchołów, nie tylko wokół sali obrad senatu i w miejscach publicznych, lecz także w królewskich komnatach i mieszkaniach, karze za przestępstwa, popełniane w otoczeniu i mieście królewskiej siedziby czy gospody albo w miejscu obrad sejmowych. A wreszcie, w czasie sejmu i w miejscu przebywania króla - on ma prawo rozdzielania gospód na kwatery oraz nakładania cen na przedmioty handlu, skąd czerpie także dochód w postaci opłaty targowej. Do marszałka należy również władza, kontrola i wymiar sprawiedliwości wobec dworzan królewskich, zarządzających stołem królewskim oraz innych urzędników dworskich, zwłaszcza jeśli chodzi o ludzi świeckich; dlatego też na publicznych zgromadzeniach i zawsze, kiedy król występuje publicznie, marszałek niesie przed monarchą wyprostowane berło drewniane czyli laskę marszałkowską. [...] Marszałek nadworny wykonuje w czasie nieobecności marszałka koronnego wszystkie czynności związane z jego urzędem. Kiedy natomiast marszałek koronny jest na miejscu, powinien przybierać sobie marszałka nadwornego za towarzysza - i zazwyczaj tak postępuje - przy załatwianiu wszelkich ważniejszych spraw. Ponadto nosi razem z nim przed królem wyprostowaną laskę marszałkowską" ${ }^{\prime 8}$.

${ }^{8}$ M. Kromer, Polska czyli o położeniu, ludności, obyczajach, urzędach i sprawach publicznych Królestwa Polskiego księgi dwie. Przekład S. Kazikowskiego. Wstęp i opracowanie M. Marchwińskiego, Olsztyn 1984, s. 124-126, 143. Tekst ten przytaczam z uwagi na to, że po raz pierwszy w literaturze podejmuje wątek marszałka. 
Autor w znacznym stopniu powtórzył tu postanowienia statutu Jana Olbrachta, nieco je rozszerzając o późniejsze regulacje dotyczące marszałków.

W konstytucji sejmowej z czasów panowania Zygmunta Augusta, uchwalonej na sejmie piotrkowskim w 1565 r., odnaleźć możemy w tytule O sposobności Urzędów Koronnych z dygnitarstwy, zalecenie aby

„Marszałek i Podskarbi Koronny, przy urzędziech swych dignitarstw nie trzymali: ponieważ, że z tychże urzędów swych, y miejsce y votum w Radzie naszey maia, y zawzdy mieć mogą: a nie mogą zaś dwojga miejsca w Radzie zasiadać"

Zakaz incompatibilitas po raz kolejny znalazł tu swe zastosowanie.

Także sejm walny z 1573 r., zwołany w związku z elekcją po śmierci ostatniego Jagiellona, podejmował wątek urzędu marszałka przy okazji formułowania spraw "pokoyu pospolitego" w czasie obierania nowego monarchy.

Możemy tu odnaleźć szeroki katalog uprawnień porządkowych marszałków przyznanych im na okres bezkrólewia. Jurysdykcją marszałkowską objęte zostały sprawy porządku i bezpieczeństwa publicznego w czasie elekcji. Zakazywano m.in. noszenia na polu elekcyjnym wszelkiej broni "okrom zwyczayney, to iest miecza, korda, szable, koncerza, szpady”. Za naruszenie tego zakazu groziła kara śmierci („ma bydź karan na gardle"). W stolicy oraz na miejscu elekcji zabronione były wszelkie zwady, tumulty czy rozruchy; chodzenie z nabitą bronia, strzelanie z niej zabronione było karą więzienia, zbiegły zaś przestępca z chwilą pojmania karany miał być śmiercią. Dobycie broni zagrożone zostało karą dwudziestu grzywien, zranienie zaś karą śmierci, podobnie jak spowodowanie zamieszek. Karą śmierci karano również zabójstwo oraz zepchnięcie z mostu, zakazane było także wtargnięcie końmi lub wozami między namioty na polu elekcyjnym, ,"a kto by tego przestać nie chciał, za napomnieniem sług Pana Marszałkowych, tak Korony Polskiej, iako y Wielkiego Xięstwa Litewskiego, każdy u swego narodu ma bydź arbitrio Senatus karan". Zagarnięcie gwałtem cudzej rzeczy skutkować miało obowiązkiem podwójnej zapłaty ograbionemu. Ograniczano także ruch kołowy w godzinach porannych i popołudniowych, by nie utrudniać poruszania się posłom oraz elektorom. Czuwać miała nad tym straż marszałkowska. Wreszcie karana przepadkiem mienia była sprzedaż wszelkich trunków na polu elekcyjnym ${ }^{10}$.

Przestrzeganie powyższych zakazów przekazano w ręce sług „Ich Mciow Panów Marszałków". Wszelkie nastawanie na nich miało podle-

\footnotetext{
${ }^{9}$ VL, t. II, Petersburg 1859, s. 45.

${ }^{10} V L$, t. II, s. 125.
} 
gać karze, z karą śmierci za zranienie włącznie. Z kolei skargi na straż marszałkowską kierować należało do marszałków. Gdyby marszałkowie czynić „sprawiedliwości nie chcieli, abo się zbraniali uczynić, tedy Ich Mość Panowie Rady i Rycerstwo, sami sprawiedliwość w tym czynić będą tu w Kole w Radzie [...] przez Deputaty, które Ich Mość Panowie Rady, także y Rycerstwo, z poyśrzodku siebie na to wysadzą" na Sądzie Kapturowym Generalnym ${ }^{11}$.

Konstytucja sejmu warszawskiego z 1589 r. określała procedencję sprawowania urzędu w czasie przebywania władcy na terenie Inflant, powierzając obowiązki u boku monarchy marszałkowi litewskiemu, z zastrzeżeniem, że w wypadku obecności obu marszałków koronnego i litewskiego pełnić je powinni tak jak w czasie obrad sejmu ${ }^{12}$.

Podobnie jak to działo się podczas pierwszej wolnej elekcji, także w 1632 r. na sejmie walnym zwołanym w związku z elekcją nowego władcy określono precyzyjnie zasady porządku i bezpieczeństwa obowiązujące w tym czasie na polu elekcyjnym oraz $\mathrm{w}$ stolicy.

Zakaz noszenia broni, z wyłączeniem białej, zagrożony był tym razem karą dwustu grzywien oraz sześcioma tygodniami wieży, nie zaś jak to było wcześniej „karaniem na gardle”. Jednak uchylanie się od sądu skutkować miało banicją. Zabronione karą grzywny było bezprawne zajmowanie wyznaczonych przez marszałków miejsc rozlokowania osób przybyłych na elekcję, jak również chodzenie „z rusznicą nabitą po mieście" oraz oddawanie $\mathrm{z}$ niej strzałów. $\mathrm{W}$ tym przypadku posesjonat płacił karę dwustu grzywien, nie posesjonat zaś karany był sześcioma miesiącami wieży. Za dobycie broni na polu elekcyjnym szlachcic miał być karany sześcioma tygodniami wieży oraz obowiązkiem zapłacenia dwustu grzywien, plebejusz zaś gardłem. Za zabicie człowieka w czasie trwania elekcji karać miano gardłem bez względu na przynależność stanową a uchylanie się od sądu skutkować miało infamią. Podobnie jak w czasie pierwszej elekcji zakazywano wszelkich zwad, uszkadzania mostów oraz spychania z nich ludzi do wody (w przypadku utonięcia groziła kara najwyższa), wjeżdżania konno na miejsce obrad, zakłócania porządku przez pachołków i służących (,a ktoby w tey mierze wystąpił, a laską albo korbaczem mu się dostało, aby to pana iego nie obrażało"). Za wszelkie towary należało płacić według taksy (obowiązującej w Warszawie i na Pradze) ustalonej przez marszałków wspólnie z wojewodą i deputatami. Karano zarówno sprzedaż powyżej ceny, jak również uchylanie się od zapłaty (w tym drugim przypadku kara wy-

\footnotetext{
11 Tamże, s. 126.

${ }^{12}$ Tamże, s. 279.
} 
nosiła podwójną wartość towaru, a niepoddanie się karze karane być miało banicją). Powtórzono przepis mówiący o zakazie ruchu kołowego w godzinach rannych i popołudniowych, a także o zakazie sprzedaży napojów alkoholowych w miejscu „gdzie Rada z rycerstwem zasiadać będzie". Zalecano przestrzeganie bezpieczeństwa przeciwpożarowego i wolność handlu. Wprowadzano zakaz wyszynku w karczmach po godzinie ósmej wieczorem. Cudzoziemcom zabraniano wstępu na pole elekcyjne. Nakazywano obyczajne zachowanie przed sądem marszałkowskim, do którego każdy pokrzywdzony mógł składać skargę. Bezwzględnie zabronione były także pojedynki pod karą pół roku wieży i sześćdziesięciu grzywien.

Wymienione powyżej czyny zabronione, popełnione w czasie elekcji, sądzone być miały przez sąd marszałkowski. Dekrety sądu przechowywać miał pisarz ziemski warszawski i wydawać na życzenie ekstrakty wyroków opatrzone swym podpisem. Same dekrety opatrzone być miały podpisami ",trzech Ichmciow PP. Deputatów: iednego z Małej, drugiego w Wielkiej Polski, a trzeciego z W.X.Lit."

Zachowanie porządku i bezpieczeństwa przekazywano na czas obrad sejmu oraz elekcji w ręce marszałków i straży marszałkowskiej. Napaść na strażników karana być miała surowo, uderzenie karano obcięciem ręki, zranienie gardłem. W przypadku naruszenia prawa przez któregoś ze „sług Ichmciow PP. Marszałków, albo Ichmciow PP. Deputatów”, miał on podlegać sądowi marszałka. Gdyby natomiast którykolwiek z asesorów sądu marszałkowskiego dopuścił się naruszenia prawa, miał odpowiadać przed tym sądem. W takim przypadku, jak również, gdy sprawa dotyczyła jego sługi, następowało wyłączenie go ze składu orzekającego. Wszystkie dekrety zapadać miały większością głosów ${ }^{13}$.

Warta przytoczenia jest rota przysięgi marszałków, znajdująca się w uchwałach tegoż sejmu, zalecająca unikanie jakiejkolwiek pomocy prawnej stronom postępowania:

„Ia N. przysięgam Panu Bogu, iż sprawiedliwie, sine ullo personarum respektu, według przysięgi na Urząd moy Marszałkowski, Regi Regnoque uczynioney, sądzić będę; spraw żadnych do sądu tego przychodzących praktykować, ani rady, ani przestrogi dawać nie będę. Secreta quoque iudicij praesentis non revelabo: sic me Deus adjuvet, et Santa Crux Christi"14.

W uchwałach sejmu obradującego w 1647 r. odnaleźć możemy Approbacya skryptu między Marszałkami, tak Koronnymi, jako y W. X. Lit. O samym

${ }^{13}$ Tamże, s. 358-360.

${ }_{14}$ Tamże, s. 361. Por. też łacińską rotę przysięgi pisarza sadu marszałkowskiego z 1678 r. (VL, t. V, Petersburg 1860, s. 315). 
tylko porządku między niemi, gdzie mowa jest o równorzędności pieczęci obu marszałków na dokumencie podpisanym przez króla ${ }^{15}$.

W uchwałach Konfederacji Generalnej Warszawskiej z lat 1632, 1648 i 1674 mowa jest o powierzeniu wykonywania przez marszałków jurysdykcji marszałkowskiej w okresie interregnum, aż do wyboru kolejnego władcy. Z kolei na sejmie koronacyjnym z 1676 r., w celu zapobieżenia tumultom skierowanym przeciwko Żydom zamieszkującym krakowski Kazimierz, udzielono marszałkom - w czasie przebywania króla w Krakowie - prawo sprawowania sądownictwa i karania winnych naruszenia porządku, rozszerzając tę jurysdykcję na okoliczne miasta i miasteczka ${ }^{16}$.

Niewątpliwie najobszerniejszą regulacją prawną dotyczącą urzędu marszałka były uchwalone na sejmie w Grodnie w 1679 r. Artykuły Sądów Marszałkowskich ${ }^{17}$. Zawierały one wyliczone w 20 punktach sprawy należące do jurysdykcji marszałków ${ }^{18}$.

Znalazły się tu m.in: zakaz jakichkolwiek zwad, buntów, tumultów itp. w miejscu rezydencji króla; zakaz tamże noszenia broni; zgłaszanie do urzędu marszałkowskiego cudzoziemców przyjeżdżających w czasie pobytu króla w mieście lub podczas obrad sejmu; zasady karania za użycie broni, zranienie; porządek ogniowy; przestrzeganie ciszy; odpowiednie traktowanie cudzoziemców; karanie wszelkich burd i zamieszek; sprawowanie nadzoru nad czeladzią dworską; zakaz napastowania ludzi innych narodowości i wyznań; karanie kradzieży i oszustw; zakaz ucztowania $\mathrm{w}$ karczmach i zajazdach po ósmej wieczorem; przestrzeganie uczciwości w handlu i niepodnoszenie cen ponad miarę; informowanie urzędu marszałkowskiego o przypadkach opatrywania rannych; walka z nierządem. W dużym stopniu było to powtórzenie wcześniej uchwalanych regulacji porządkowych, dodano jednak kilka nowych.

Na wstępie podkreślono „aby żaden cujuscunque status et conditionis, tam advena, Quam indygena, excepto nemine, nie śmiał, ani się ważył, tak w domach iako y na ulicach żadnych zwad y zamowek czynić, uszczypliwych słow, bonam famam laedentia drugiemu mówić, ani tumultow, sedicyi, odpowiedzi na zdrowie czynić, In duellum drugiego nie wyzywać, na gospody cudze y domy gwałtownie nachodzić, y nasyłać, ani krzywdy swey y urazy iakieykolwiek privata authoritate, ale urzędownie dochodzić; ktoby inaczej sobie postąpił, ma bydź in recenti facto et crimine, sine ullis

\footnotetext{
${ }^{15} V L$, t. IV, Petersburg 1859, s. 69.

${ }^{16} V L$, t. V, s. 192.

${ }^{17}$ Tamże, s. 314-317.

${ }^{18}$ Szerzej na ten temat J. Rafacz, Więzienie marszalkowskie w latach 1767-1795...
} 
exceptionibus przez Urząd Marszałkowski sądzony, y za występek swoy podług prawa y zwyczaiu karany"19.

Do wcześniej wyartykułowanych zakazów dodano m.in. obowiązek zachowania respektu wobec posłów zagranicznych oraz ich służących; zakaz uprawiania hazardu, nieprzestrzeganie którego karane być miało pręgierzem i wygnaniem z miasta, ponowne zaś schwytanie sprawcy zagrożone było śmiercią. Cyrulicy zobowiązani zostali do zgłaszania marszałkom wszelkich przypadków opatrywania ran, z podaniem nazwiska zranionego oraz sprawcy tego czynu. $\mathrm{W}$ ostatnim punkcie dodano zakaz uprawiania nierządu. Treść tego artykułu z racji oryginalności sformułowań zasługuje na przytoczenie:

„Białegłowy nierządne, ktoreby się uczciwym a potrzebnym handlem, y robotami nie bawiły, mężów swych nie miały (podkr. moje JM), aby w mieście y po przedmieściach zaraz nie były y nie mięszkały; a ktoraby się bawiła y znaleść miała, ma bydź pojmana, u pręgierza sieczona, y na uszach naznaczona" ${ }^{20}$.

Można zatem domniemywać istnienie i takich "nierządnic”, które uczciwie handlowały, pracowały i były zamężne. Zarazem zauważyć można troskę władz o odpowiednie morale imć panów senatorów, posłów i elektorów. Chodziło zapewne o to, by nie tracili oni cennego czasu na nieprzyzwoite rozrywki, poświęcają się bez reszty służbie publicznej. Przyjęte tu wzorce zasługują być może na przypomnienie...

Władza urzędu marszałkowskiego, jak podkreślono, miała się rozciągać na osoby wszelkiego stanu, bez względu na przysługujące im przywileje czy też właściwość sądu (forum competens).

Dokument opatrzony został podpisem marszałka wielkiego litewskiego Aleksandra Hilarego Połubińskiego, z uwagi na fakt, że sejm obradował w Grodnie. Approbacja artykułów sądów marszałkowskich za zgodą Stanów przyjęta, in Volumen Legum miała zostać włączona.

Ostatnią uchwaloną w wieku XVII ustawą sejmową poświęconą marszałkom była przyjęta na sejmie w 1699 r. konstytucja nosząca tytuł Bespieczeństwo władzy. Stanowi ona reasumpcję wcześniejszych artykułów marszałkowskich, z zaleceniem, aby „one Wielmożni Marszałkowie obojga narodów do exekucyi contra delinguentes przywodzili sub amissione Officiorum praesenti lege $[\ldots]^{\prime 21}$.

Jak wyżej wspomniano, oprócz konstytucji sejmowych o roli i kompetencjach marszałków sporo pisano w staropolskiej literaturze prawni-

\footnotetext{
${ }^{19}$ VL, t. V, s. 315.

${ }^{20}$ Tamże, s. 317.

${ }^{21} V L$, t. VI, Petersburg 1860, s. 33.
} 
czej. Z uwagi na podjęcie tego wątku we wcześniejszym opracowaniu, odsyłam w tym miejscu do przywołanej wyżej pracy ${ }^{22}$.

W drugiej połowie wieku XVIII urząd marszałka uległ istotnym przekształceniom. Pozbawiony szeregu wcześniejszych funkcji, jak choćby od 1766 r. zarządzania dworem, czy sądzenia popełnionych w obliczu majestatu przestępstw kryminalnych, zachował prawo jurysdykcji marszałkowskiej, sprawując ją do końca I Rzeczypospolitej. Jednocześnie podejmowane i po części realizowane w czasach stanisławowskich reformy ustrojowe, w szczególności ustawodawstwo Sejmu Wielkiego, szły już w kierunku nowoczesnych form zarządu państwem, opierając strukturę władzy na stosowanych w większości krajów europejskich zasadach biurokratyzmu i kolegialności. Tym sposobem urząd marszałka tracił stopniowo swój dawny charakter urzędu centralnego monarchy, stając się coraz bardziej urzędem ministerialnym we współczesnym rozumieniu tego terminu. Jako swoisty „minister policji” przewodniczył od 1775 r. Departamentowi Policji Rady Nieustającej, by następnie wejść w skład rządu, jakim była Straż Praw, a także stanąć na czele Komisji Rządowej Policji Obojga Narodów. Po upadku I Rzeczypospolitej, recypowany w Księstwie Warszawskim napoleoński model ustrojowy ostatecznie zerwał ze staropolskim systemem i nomenklaturą urzędów, zarząd centralny państwem przekazując w ręce jednoosobowo działających ministrów, w tym także ministra policji.

\section{Bibliografia}

\section{Źródła drukowane}

Volumina Legum, t. I, II, IV, V, VI, Petersburg 1859-1860.

\section{Opracowania}

Bandtkie J. W., Rozprawy o prawie $i$ sadownictwie karzacem $i$ urzędach $w$ dawnej Polsce, Warszawa 1868.

Baranowski J., Marszałek F. Bieliński, Warszawa 1919.

Chłapowski K., Elita senatorsko-dygnitarska Korony za czasów Zygmunta III i Wtadystawa IV, Warszawa 1996.

Ciara S., Senatorowie i dygnitarze koronni w II połowie XVII wieku, Wrocław 1990.

Fuchs F., Ustrój dworu królewskiego za Stefana Batorego, [w:] Studia historyczne ku czci Prof. Wincentego Zakrzewskiego, Kraków 1908.

Góralski Z., Urzędy i godności w dawnej Polsce, Warszawa 1983.

Jankowska J., Akta urzędu marszałka wielkiego koronnego 1611-1794, [w:] Straty archiwów i bibliotek warszawskich w zakresie rękopiśmiennych źródeł historycznych, t. I, Archiwum Główne Akt Dawnych, Warszawa 1957.

${ }^{22}$ Urzad marszatkowski w literaturze prawniczej XVI-XVIII wieku, [w:] Myśl i polityka. Księga Pamiatkowa dedykowana Profesorowi Jackowi Marii Majchrowskiemu..., s. 377-382. 
Jankowska J., Akta urzędu marszałkowskiego koronnego, [w:] Archiwum Główne Akt Dawnych w Warszawie. Przewodnik po zespołach, t. I, Archiwa dawnej Rzeczypospolitej, red. J. Karwasińska, Warszawa 1958.

Kromer M., Polska czyli o położeniu, ludności, obyczajach, urzędach i sprawach publicznych Królestwa Polskiego księgi dwie. Przekład S. Kazikowskiego. Wstęp i opracowanie M. Marchwińskiego, Olsztyn 1984.

Kutrzeba S., Urzędy koronne $i$ dworskie w Polsce, ich poczattki i rozwój do r. 1504, „Przewodnik Naukowy i Literacki” 1903, t. XXXI.

Lelewel J., Dostojności i urzędy, [w:] Polska, dzieje i rzeczy jej, t. IV, Poznań 1856.

Malec J., Urzad marszałkowski w literaturze prawniczej XVI-XVIII wieku, [w:] Myśl i polityka. Księga Pamiatkowa dedykowana Profesorowi Jackowi Marii Majchrowskiemu, red. naukowa B. Szlachta, Kraków 2011.

Malec J., Z badań nad urzędem marszałkowskim koronnym w Rzeczypospolitej szlacheckiej, [w:] Studia z Historii Ustroju i Prawa. Księga dedykowana Profesorowi Jerzemu Walachowiczowi, red. H. Olszewski. Prace Wydziału Prawa i Administracji Uniwersytetu im. Adama Mickiewicza w Poznaniu, t. VII, Poznań 2002.

Markiewicz M., Rady senatorskie Augusta II [1697-1733], Wrocław 1988.

Perzanowska H., Urząd marszałkowski w okresie rządów Józefa Mniszcha, AUWr, Historia XII, 1966, nr 54 [Wrocław].

Rafacz J., Więzienie marszałkowskie w latach 1767-1795, [w:] Studia nad historia prawa polskiego, red. O. Balzer, t. XII, z. 2, Lwów 1932.

Sucheni-Grabowska A., Badania nad elitą władzy wlatach 1551-1562, [w:] Społeczeństwo staropolskie, t. I, Warszawa 1976.

Suchocki W., O marszałkach wielkich i nadwornych Królestwa Polskiego, „Dziennik Warszawski" 1826, t. V.

Tyszkowski W., Z cenzorskiej działalności jurysdykcji marszałkowskiej w Warszawie. Spalenie numeru "Gazette d'Utrecht”, z 21 czerwca 1768 r., „Ze skarbca kultury” 1980, z. 33.

Wiśniewski K., Urząd marszałkowski koronny w bezkrólewiach XVII i XVIII wieku (1632-1736), Warszawa 2005.

Wrede M. Marszałkowie wielcy i nadworni koronni. Wnioski z biogramów, [w:] Władza i społeczeństwo w XVI i XVII wieku, Warszawa 1989.

Zielińska T., Kwestia bezpłatności urzędów pulicznych w Rzeczypospolitej, [w:] Władza i społeczeństwo w XVI i XVII wieku, Warszawa 1989.

Zielińska T., Magnateria polska epoki saskiej. Funkcje urzędów i królewszczyzn w procesie przeobrażeń warstwy społecznej, Warszawa 1977. 